JARES, Vol. 5 No. 1 March, 2020; p-ISSN: 2502-826X; e-ISSN: 2503-1163

Copyrights@ Balitar Islamic University, Blitar, Indonesia;

https://ejournal.unisbablitar.ac.id/index.php/jares

Citation: Azzahra, K. (2020). THE INFLUENCE OF INTELLECTUAL CAPITAL AND SHARIA

COMPLIANCE TO THE BANKING FINANCIAL PERFORMANCE IN INDONESIA. JARES

(Journal of Academic Research and Sciences), 5(1), 14-26. https://doi.org/10.35457/jares.v5i1.900

\title{
THE INFLUENCE OF INTELLECTUAL CAPITAL AND SHARIA COMPLIANCE TO THE BANKING FINANCIAL PERFORMANCE IN INDONESIA
}

\author{
Khoirunnisa Azzahra \\ Fakultas Ekonomi, Universitas Pamulang \\ Email; Khoirunnisa.azzahra13@gmail.com
}

\begin{abstract}
This study aims to analyze the effect of intellectual capital and Sharia Compliance on Financial Performance. This study also uses several variables that are identified as factors that affect Financial Performance including intellectual capital as measured by using Value Added Intellectual Coefficient (VAIC), and sharia compliance as measured by using Islamic Income Ratio (IsIR) proxy. The research method used is quantitative descriptive by using multiple linear regression test models. Sampling was carried out using a purposive sampling method so that 7 Islamic banks in Indonesia were obtained with 42 researched data used as research samples and hypothesis testing was performed using simultaneous significant tests ( $F$ test) and partial significant tests ( $t$ test) with $a=5 \%$. F Test results show that intellectual capital, and sharia compliance together have a significant positive effect on financial performance. T test results show that intellectual capital and Sharia Compliance have a significant positive effect on financial performance.
\end{abstract}

Keywords: Intellectual Capital, Sharia Compliance, Financial Performance

\section{INTRODUCTION}

Banks are business entities that collect funds from the public in the form of deposits and distribute them to the public in the form of credit and or other forms in order to improve the standard of living of the people (Law No. 10 of 1998). In Indonesia, the development of sharia-based banks is now experiencing rapid progress. This was preceded by the development of the Islamic economy in Indonesia which showed a success. It has become common knowledge that the development of Islamic economics begins with the emergence of Islamic financial institutions.

The development of Islamic banks has implications for the challenges that must be faced by Islamic banks, where the biggest challenge is to maintain the image and good name in the eyes of customers in order to maintain customer trust and loyalty to Islamic banks (Falikhatun, 2012: 2). The development of Islamic banking today is still far from expectations. If you look at the Muslim population which is the largest in the world, it does not guarantee the rapid development of Islamic banking. Even the financial performance of Islamic banks is not as long as conventional banks. It can be seen from the return on assets (ROA) of sharia banking that continues to decline. In 2012 ROA of Islamic banking still stood at $2.14 \%$, the following year it declined and continued to decline until the peak occurred in 2014 with ROA of $0.79 \%$. Bank failures, including Islamic banks, are currently 
JARES, Vol. 5 No. 1 March, 2020; p-ISSN: 2502-826X; e-ISSN: 2503-1163

Copyrights@Balitar Islamic University, Blitar, Indonesia;

https://ejournal.unisbablitar.ac.id/index.php/jares

Citation: Azzahra, K. (2020). THE INFLUENCE OF INTELLECTUAL CAPITAL AND SHARIA

COMPLIANCE TO THE BANKING FINANCIAL PERFORMANCE IN INDONESIA. JARES

(Journal of Academic Research and Sciences), 5(1), 14-26. https://doi.org/10.35457/jares.v5i1.900

more due to governance problems. (www.neraca.co.id)

The level of financial performance of a bank can affect public confidence in the bank.

Because basically community assessment is seen from the implied measure such as facilities, services and profit levels. So as an institution that in its activities using funds from the public bank is required to maintain and improve its performance (Astutik, 2015: 3). One of the most appropriate indicators to measure a company's performance is profitability. The company's ability to generate profits can be used as a benchmark for company performance. The higher the profitability, the better the company's financial performance. One measurement that can be used in measuring the company's financial performance is Return On Assets (ROA). If the company's profits increase or decrease, ROA will experience changes so that the measurement in research uses ROA. Performance measurements are important to assess the performance of bank management and to make plans for future performance improvement. Performance can be influenced by several variables while the variables that influence in this study are intellectual capital and sharia compliance.

Intellectual capital is an intangible asset in the form of information and knowledge resources that serves to improve competitiveness and can improve company performance and corporate value. According to the International Federation of Accountants (IFAC), there are several terms that are almost similar to intellectual capital, including intellectual property, intellectual assets, knowledge assets, all of which are intended as shares or capital based on knowledge owned by the company. While sharia compliance is a manifestation of the fulfillment of all sharia principles in financial institutions that have the form, characteristics, integrity and credibility of sharia banks. where the culture of compliance is the values, behaviors and actions that support the creation of sharia bank compliance with all Bank Indonesia regulations (Bank Indonesia Regulation Number 13/2 / PBI / 2011).

Research on Intellectual Capital is believed to play an important role in increasing company value and financial performance. (Chen, 2005), (Tan, 2007), and (Ulum, 2008) have proven that Intellectual capital (VAICTM) has a positive influence on a company's financial performance by using the Pulic model as a measure of a company's intellectual abilities. Several studies have been conducted to measure the effect of intellectual capital on financial performance, but research shows different results. The inconsistency of research 
JARES, Vol. 5 No. 1 March, 2020; p-ISSN: 2502-826X; e-ISSN: 2503-1163

Copyrights@Balitar Islamic University, Blitar, Indonesia;

https://ejournal.unisbablitar.ac.id/index.php/jares

Citation: Azzahra, K. (2020). THE INFLUENCE OF INTELLECTUAL CAPITAL AND SHARIA

COMPLIANCE TO THE BANKING FINANCIAL PERFORMANCE IN INDONESIA. JARES

(Journal of Academic Research and Sciences), 5(1), 14-26. https://doi.org/10.35457/jares.v5i1.900

results regarding the relationship of intellectual capital with company performance has attracted researchers to retest with a different model from previous tests. This study seeks to measure the effect of intellectual capital by using Value Added Capital Employed (VACA), Value Added Human Capital (VAHU), and Structural Capital Value Added (STVA) on the company's financial performance as measured by using the variable Return on Assets (ROA), Return on Equity (ROE) in financial sector companies (Banks, Financing Institutions, Securities Companies, Insurance Companies, and Financial Institutions) listed on the Indonesia Stock Exchange with observation periods from 2011-2013. The choice of the financial sector is because the financial sector is one of the most intellectually intensive sectors. In addition, from an intellectual aspect, overall employees in the banking sector are more homogeneous compared to other economic sectors (Kubo, 2002).

Based on the background that has been described, the formulation of the problems in this study are (1) whether intellectual capital influences financial performance (2) whether sharia compliance affects financial performance and (3) whether intellectual capital and sharia compliance simultaneously affect financial performance. This study aims to test empirically in analyzing the effect of intellectual and shariah compliance on financial performance both partially and simultaneously.

\section{LITERATURE RIVIEW}

\section{Intellectual Capital}

Intellectual capital is an intangible asset in the form of information and knowledge resources that serve to improve competitiveness and improve company performance.

According to the International Federation of Accountants (IFAC), there are several terms that are almost similar to intellectual capital, including intellectual property, intellectual assets, knowledge assets, all of which are intended as shares or capital based on knowledge owned by the company (Widyaningrum, 2004).

Pulic $(1998 ; 1999 ; 2000)$ does not directly measure a company's intellectual capital, but proposes a measure to assess the efficiency of added value as a result of the company's intellectual ability (Value Added Intellectual Coefficient - 3 VAIC): 
JARES, Vol. 5 No. 1 March, 2020; p-ISSN: 2502-826X; e-ISSN: 2503-1163

Copyrights@ Balitar Islamic University, Blitar, Indonesia;

https://ejournal.unisbablitar.ac.id/index.php/jares

Citation: Azzahra, K. (2020). THE INFLUENCE OF INTELLECTUAL CAPITAL AND SHARIA

COMPLIANCE TO THE BANKING FINANCIAL PERFORMANCE IN INDONESIA. JARES

(Journal of Academic Research and Sciences), 5(1), 14-26. https://doi.org/10.35457/jares.v5i1.900

VAIC $^{\text {TM }}=$ VACA $_{i}+$ VAHU $_{i}+$ STVA $_{i}$

\section{Sharia Compliance}

Shariah compliance is the compliance of sharia banks to sharia principles. Islamic banks are financial institutions that operate in accordance with Islamic principles, meaning that banks operate in accordance with Islamic sharia provisions, especially regarding the procedures for Islamic prayerfulness (El junusi, 1833)

Sharia compliance is the fulfillment of sharia values in sharia financial institutions (in this case sharia banking) which makes the MUI DSN fatwa and Bank Indonesia (BI) regulations a measure of compliance with sharia principles, both in production, transactions and operations at sharia banks. (Andini, 2016).

\section{FINANCIAL PERFORMANCE}

Financial performance is the work performance that has been achieved by the company in a certain period and stated in the financial statements of the company concerned (Munawir, 2010). The purpose of management is to maximize the value of the company to achieve this goal, the company must take advantage of the strengths of the company and continuously improve the existing weaknesses. One way is to measure financial performance by analyzing financial statements using financial ratios (Munawir, 2010 in Mayangsari and Andayani, 2015: 60)

\section{Research Model}

The Research Model of this research is below

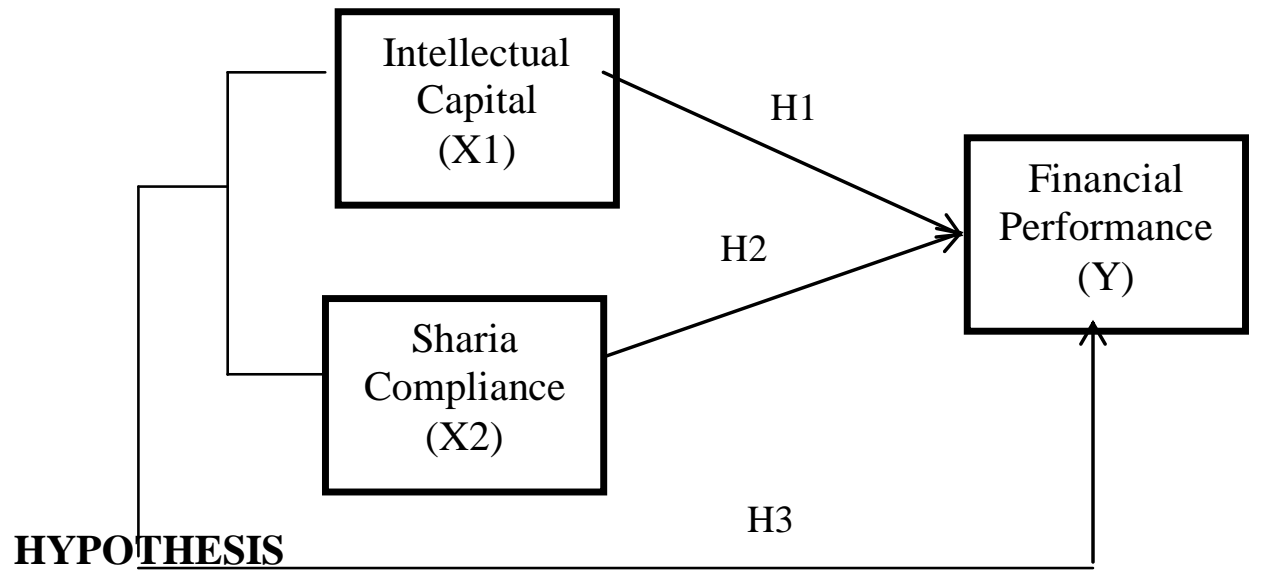


JARES, Vol. 5 No. 1 March, 2020; p-ISSN: 2502-826X; e-ISSN: 2503-1163

Copyrights@Balitar Islamic University, Blitar, Indonesia;

https://ejournal.unisbablitar.ac.id/index.php/jares

Citation: Azzahra, K. (2020). THE INFLUENCE OF INTELLECTUAL CAPITAL AND SHARIA COMPLIANCE TO THE BANKING FINANCIAL PERFORMANCE IN INDONESIA. JARES

(Journal of Academic Research and Sciences), 5(1), 14-26. https://doi.org/10.35457/jares.v5i1.900

1. The Influence of Intellectual Capital to the Financial Performance

Intellectual capital is a component of non-permanent assets consisting of knowledge or thinking power owned by the company, which can provide added value to the company. Increasing the company will have a competitive advantage by managing Intellectual Capital. According to the results of research conducted by Yusro Rahma (2018) which shows that the Value Added Intellectual Capital (VAIC) has a positive and significant effect on Return On Assets (Profitability) / financial performance. Based on the theory and research proposed, the hypotheses proposed in this study are as follows:

\section{H1 : Intellectual Capital is suspected to influence Financial Performance}

2. The Influence of Sharia Compliance to the Financial Performance

One important pillar in the development of Islamic banks is sharia compliance. This pillar is the main differentiator between Islamic banks and conventional banks. To guarantee the application of sharia principles in banking institutions, sharia supervision is needed which is sacrificed by the Sharia Supervisory Board (DPS) (El Junusi, 2012: 1831). According to the results of a study conducted by Fajar Budiman (2017) which examined the effects of sharia compliance and Islamic corporate governance that can be concluded conclusively, Islamic Income Ratio (IsIR) has a significant influence on the Financial Performance of Islamic Commercial Banks. Based on the theory and previous research, the hypotheses proposed in this study are as follows:

\section{$\mathrm{H}_{2}$ : Sharia Compliance is suspected to influence Financial Performance}

\section{RESEARCH METHODE}

Based on the problems studied, this study uses quantitative research with descriptive methods. Quantitative research methods proposed by Sugiyono (2017: 8) are research methods based on the philosophy of positivism used to examine populations or specific samples, data collection using research instruments, quantitative / statistical data analysis, with the aim to test hypotheses that have been set.

This research was conducted in all Islamic banking registered at Bank Indonesia for the period 2013 - 2018. The dependent and independent variables in this study are as follows:

\section{Financial Performance}


JARES, Vol. 5 No. 1 March, 2020; p-ISSN: 2502-826X; e-ISSN: 2503-1163

Copyrights@ Balitar Islamic University, Blitar, Indonesia;

https://ejournal.unisbablitar.ac.id/index.php/jares

Citation: Azzahra, K. (2020). THE INFLUENCE OF INTELLECTUAL CAPITAL AND SHARIA

COMPLIANCE TO THE BANKING FINANCIAL PERFORMANCE IN INDONESIA. JARES

(Journal of Academic Research and Sciences), 5(1), 14-26. https://doi.org/10.35457/jares.v5i1.900

Financial performance is a picture of the financial condition of a bank in a given period, including aspects of raising funds and channeling funds. Financial performance in this study was measured using Return on Assets (ROA).

ROA can be calculated using the following formula:

$$
\text { ROA }=\frac{\text { Earning before tax }}{\text { Total Assets }} \times 100 \%
$$

ROA can be calculated using the following formula:

\section{Intellectual Capital}

Intellectual Capital is measured by the Value Added Intellectual Coefficient (VAICTM) developed by Pulic (1998). This method uses three proxy calculations, namely:

1. Value Added Human Capital (VAHU)

Value added human capital (VAHU) is a comparison between value added (VA) and costs incurred by companies to improve the performance and knowledge of their employees (human capital). value added and VAHU can be calculated using the following formula:

$$
\begin{array}{cl}
\cline { 2 - 3 } & \multicolumn{1}{l|}{\begin{array}{l}
\text { KA }=\text { output }- \text { input } \\
\text { VAHU }
\end{array}} \\
\text { Keterangan } \mathbf{H C}
\end{array}
$$

1. Structural Capital Value Added (SCVA)

Structural capital value added (SCVA) shows the contribution of structural capital (SC) in the process of creating value added (VA). SCVA measures the number of SC needed to produce VA and is an indication of how successful SC is in the value creation process (Kuryanto and Syafruddin, 2008)

According to Horibe (quoted by Yudianti, 2000), structural capital is a means to transform human capital into corporate / organizational welfare. SCVA values, 
JARES, Vol. 5 No. 1 March, 2020; p-ISSN: 2502-826X; e-ISSN: 2503-1163

Copyrights@ Balitar Islamic University, Blitar, Indonesia;

https://ejournal.unisbablitar.ac.id/index.php/jares

Citation: Azzahra, K. (2020). THE INFLUENCE OF INTELLECTUAL CAPITAL AND SHARIA

COMPLIANCE TO THE BANKING FINANCIAL PERFORMANCE IN INDONESIA. JARES

(Journal of Academic Research and Sciences), 5(1), 14-26. https://doi.org/10.35457/jares.v5i1.900

according to the Pulic model, are obtained from:

$$
\text { SCVA }=(\text { VA-HC)/VA }
$$

Keterangan :

$$
\begin{array}{ll}
\text { SCVA } & =\text { Struktural Capital Value Added } \\
\text { HC } & =\text { Human Capital employe expense) } \\
\text { VA } & =\text { Value Added }
\end{array}
$$

2. Value Added Capital Employed (VACA)

Chen et al. (2005) defines value added as the net value created by companies, including employees, creditors, stakeholders, and the government during the year.

The formula for value added is as follows:

$$
\begin{array}{cl}
\hline \text { VACA }=\text { VA/CE } \\
\text { Keterangan : } \\
\text { VACA } & =\text { Value Added Capital Employed } \\
\text { CE } & =\text { Capital Employed ( ekuitas and net income) } \\
\text { VA } & =\text { Value Added }
\end{array}
$$

3. Value Added Intellectual Coefficient (VAIC)

From the three proxies, the Value Added Intellectual Capital Coefficient (VAICTM) formula can be obtained as follows:

$$
V A I C^{T M}=V A C A_{i}+V A H U_{i}+S T V A_{i}
$$

\section{Sharia Compliance}

Sharia Compliance or sharia compliance is the implementation of sharia principles as measured by the level of compliance of sharia banks to the implementation of sharia principles in the collection and distribution of Islamic bank funds (Hameed et al, 2004: 5). In this study sharia compliance was measured using an Islamic Income Ratio (IsIR) proxy.

Islamic Income Ratio is used to show the percentage of how much halal income is obtained compared to the total Islamic halal income plus non-halal income. Islamic Income Ratio can be calculated by the formula: 
JARES, Vol. 5 No. 1 March, 2020; p-ISSN: 2502-826X; e-ISSN: 2503-1163

Copyrights@ Balitar Islamic University, Blitar, Indonesia;

https://ejournal.unisbablitar.ac.id/index.php/jares

Citation: Azzahra, K. (2020). THE INFLUENCE OF INTELLECTUAL CAPITAL AND SHARIA

COMPLIANCE TO THE BANKING FINANCIAL PERFORMANCE IN INDONESIA. JARES

(Journal of Academic Research and Sciences), 5(1), 14-26. https://doi.org/10.35457/jares.v5i1.900

$$
\operatorname{IsIR}=\frac{\operatorname{IsIn}}{\operatorname{IsIn}+\mathrm{N} \operatorname{IsIn}}
$$

\section{POPULATION AND SAMPLE}

The population used in this study is all Islamic banking listed on the Indonesia Stock Exchange (IDX) for the period of 2013 - 2018. The population is 14 and not all of these populations will be the object of research, so further sampling is needed by the purposive sample method. sampling. The following details on determining the sample can be seen in table 1 below:

Tabel 1

Selection sample

\begin{tabular}{|c|l|c|}
\hline No & \multicolumn{1}{|c|}{ Kriteria } & $\begin{array}{c}\text { Jumlah } \\
\text { Perbankan }\end{array}$ \\
\hline 1 & $\begin{array}{l}\text { Sharia Commercial Bank registered with the Financial } \\
\text { Services Authority for the period 2013-2018 }\end{array}$ & 14 \\
\hline 2 & $\begin{array}{l}\text { Sharia Commercial Bank which does not publish the } \\
\text { available and complete annual financial statements in } \\
\text { the 2013-2018 period }\end{array}$ & 7 \\
\hline 3 & $\begin{array}{l}\text { Data relating to research variables are available in full } \\
\text { (overall data available and published in the 2013-2018 } \\
\text { period). }\end{array}$ & 7 \\
\hline The number of samples that meet the criteria & 6 \\
\hline Research period & 42 \\
\hline \multicolumn{2}{|l|}{ Total sample data for the period 2013-2018 } \\
\hline
\end{tabular}

Source: Data processed by the author

\section{Analysis Technique}

The data analysis method in this study uses descriptive statistics and multiple regression analysis with the help of Statistical Product and Service Solution (SPSS) version 22.0

\section{RESULTS AND DISCUSSION}

Descriptive statistical analysis is used to provide a statistical description of the independent and dependent variables in the study. The variables in this study will be tested 
JARES, Vol. 5 No. 1 March, 2020; p-ISSN: 2502-826X; e-ISSN: 2503-1163

Copyrights@ Balitar Islamic University, Blitar, Indonesia;

https://ejournal.unisbablitar.ac.id/index.php/jares

Citation: Azzahra, K. (2020). THE INFLUENCE OF INTELLECTUAL CAPITAL AND SHARIA

COMPLIANCE TO THE BANKING FINANCIAL PERFORMANCE IN INDONESIA. JARES

(Journal of Academic Research and Sciences), 5(1), 14-26. https://doi.org/10.35457/jares.v5i1.900

statistically descriptive as shown in table 2 below:

Tabel 2

Descriptive Statistics Test Results

Descriptive Statistics

\begin{tabular}{|l|r|r|r|r|r|}
\hline & \multicolumn{1}{|c|}{$\mathrm{N}$} & \multicolumn{1}{c|}{$\begin{array}{c}\text { Minimu } \\
\mathrm{m}\end{array}$} & $\begin{array}{c}\text { Maximu } \\
\mathrm{m}\end{array}$ & \multicolumn{1}{c|}{ Mean } & \multicolumn{1}{c|}{$\begin{array}{c}\text { Std. } \\
\text { Deviation }\end{array}$} \\
\hline Intellectual & 42 & $-5,41$ & 8,06 & 4,6424 & 2,41654 \\
Capital & 42 & 1,00 & 1,00 &, 9996 &, 00050 \\
Sharia Compliace & 42 & $-1,12$ & 2,63 &, 8321 &, 75200 \\
Financial & 42 & & & & \\
Performance & & & \\
Valid N (listwise) & & &
\end{tabular}

From the table above it can be seen that for financial performance variables have a minimum value of -1.12 , a maximum value of 2.63 and a mean value of 0.8321 with a standard deviation of 0.75200 . The intellectual capital variable has a minimum value of 5.41, a maximum value of 8.06 and a mean value of 4.6424 with a standard deviation of 2.41654. The Sharia Compliance variable has a minimum value of 1.00 , a maximum value of 1.00 and a mean value of 0.9996 with a standard deviation of 0,00050 .

\section{HYPOTHESIS TEST RESULTS}

\section{T TEST}

Tabel 3

Partial Test Results (t Test)

Coefficients $^{\mathbf{a}}$

\begin{tabular}{|c|c|c|c|c|c|c|}
\hline \multirow{2}{*}{\multicolumn{2}{|c|}{ Model }} & \multicolumn{2}{|c|}{$\begin{array}{c}\text { Unstandardized } \\
\text { Coefficients }\end{array}$} & \multirow{2}{*}{$\begin{array}{c}\text { Standardized } \\
\text { Coefficients } \\
\text { Beta }\end{array}$} & & \multirow[b]{2}{*}{ Sig. } \\
\hline & & $\mathrm{B}$ & Std. Error & & & \\
\hline & $\begin{array}{l}\text { (Consta } \\
\text { nt) }\end{array}$ & $-480,542$ & 148,429 & & $-3,238$ & ,003 \\
\hline & Lag_X1 & ,001 & ,000 & ,336 & 2,357 &, 024 \\
\hline & Lag_X2 & 758,388 & 233,857 & ,459 & 3,243 & ,002 \\
\hline
\end{tabular}

a. Dependent Variable: Lag_Y

$\mathrm{RO}$

$\mathrm{M}$ the results of the persial test ( $\mathrm{t}$ test) of table 3 above, the results of this research prove as follows:

1. The Influence of Intellectual Capital to the Financial Performance 
JARES, Vol. 5 No. 1 March, 2020; p-ISSN: 2502-826X; e-ISSN: 2503-1163

Copyrights@Balitar Islamic University, Blitar, Indonesia;

https://ejournal.unisbablitar.ac.id/index.php/jares

Citation: Azzahra, K. (2020). THE INFLUENCE OF INTELLECTUAL CAPITAL AND SHARIA

COMPLIANCE TO THE BANKING FINANCIAL PERFORMANCE IN INDONESIA. JARES

(Journal of Academic Research and Sciences), 5(1), 14-26. https://doi.org/10.35457/jares.v5i1.900

Based on the partial test results ( $\mathrm{t}$ test), it can be obtained that the tcount is 2.357 with a significant value of 0.003 with a value below 0.05 and a table of 2.01954 . This means that it can be concluded that intellectual capital has a positive and significant effect on financial performance.

2. The Influence of Sharia Compliance to the Financial Performance

Based on the partial test results ( $\mathrm{t}$ test), it can be obtained the tcount of 3.243 with a significant value of 0.002 with a value below 0.05 and a table of 2.01954. This means that it can be concluded that Sharia Compliance has a positive and significant effect on financial performance.

\section{F TEST}

Tabel 4

Simultaneous Test Results (Test F)

\begin{tabular}{|c|c|c|c|c|c|c|}
\hline \multicolumn{7}{|c|}{ ANOVA $^{a}$} \\
\hline & & $\begin{array}{l}\text { Sum of } \\
\text { Squares }\end{array}$ & Df & Mean Square & $\mathrm{F}$ & Sig. \\
\hline \multirow{3}{*}{$\frac{1 \mathrm{vi}}{1}$} & Regression & 4,724 & 2 & 2,362 & $\overline{5,996}$ &, $005^{b}$ \\
\hline & Residual & 14,971 & 39 & ,394 & & \\
\hline & Total & 19,695 & 41 & & & \\
\hline
\end{tabular}

a. Dependent Variable: Lag_Y

b. Predictors: (Constant), Lag_X2, Lag_X1

From the $\mathrm{F}$ test results in table 4 above, it shows that the fcount value of 5.996 with a significant level of 0.005 whose value is smaller than 0.05 , so it can be concluded that the independent variable has a significant effect on the dependent variable. While fcount 5.996> Ftable 3.23 means that all independent variables simultaneously have a significant effect on the dependent variable.

\section{DISCUSSION}

\section{The Influence of Intellectual Capital to the Financial Performance}

Intellectual capital has a positive and significant effect on financial performance through the ROA proxy, this occurs because intellectual capital is intellectual property 
JARES, Vol. 5 No. 1 March, 2020; p-ISSN: 2502-826X; e-ISSN: 2503-1163

Copyrights@Balitar Islamic University, Blitar, Indonesia;

https://ejournal.unisbablitar.ac.id/index.php/jares

Citation: Azzahra, K. (2020). THE INFLUENCE OF INTELLECTUAL CAPITAL AND SHARIA

COMPLIANCE TO THE BANKING FINANCIAL PERFORMANCE IN INDONESIA. JARES

(Journal of Academic Research and Sciences), 5(1), 14-26. https://doi.org/10.35457/jares.v5i1.900

centered on human resources that functions to improve the competitiveness of human resources owned by the company, If the ability of human resources is getting better, then expected to produce good performance for the company, so that the profitability of Return On Assets is increasing. Based on resource-based theory, companies will excel in business competition and get good financial performance by owning, controlling and utilizing important strategic assets (tangible and intangible assets). Intellectual capital is believed to play an important role in increasing company value and financial performance (ROA). These results support the research of Ulum et al (2008), and Kurniawan (2013), showing that Intellectual Capital has a positive effect on ROA. But these results are not in line with research by Rismawati and Sanjaya (2013), which states that Intellectual Capital has no significant effect on company performance (ROA).

\section{The Influence of Sharia Compliance to the Financial Performance}

Sharia compliance has a positive and significant effect on financial performance because Sharia compliance is one of the important pillars in the development of Sharia Banks, because these pillars are the difference between Sharia Banks and Conventional Banks. For this reason, Sharia Banks must maintain consistent operation of their companies with sharia principles so that customers will trust them and the level of company performance will improve. And financial performance will also increase. This study is in line with Budiman's research (2017) "The Effect of Sharia Compliance and Islamic Corporate Governance on Financial Performance of Islamic Commercial Banks" which states that Sharia Compliance which is proxied by ISiR has a positive effect on financial performance.

\section{CONCLUSION}

Based on the results of research and discussion that has been described previously, some conclusions drawn are as follows:

1. Intellectual Capital has a positive and significant effect on financial performance, if banks /companies have competent human resources, infrastructure within the company supports and has good relations with customers/relationships, it is expected to produce good 
JARES, Vol. 5 No. 1 March, 2020; p-ISSN: 2502-826X; e-ISSN: 2503-1163

Copyrights@Balitar Islamic University, Blitar, Indonesia;

https://ejournal.unisbablitar.ac.id/index.php/jares

Citation: Azzahra, K. (2020). THE INFLUENCE OF INTELLECTUAL CAPITAL AND SHARIA COMPLIANCE TO THE BANKING FINANCIAL PERFORMANCE IN INDONESIA. JARES

(Journal of Academic Research and Sciences), 5(1), 14-26. https://doi.org/10.35457/jares.v5i1.900

financial performance for the company, so that profitability returns on assets will increase.

2. Sharia compliance has a positive and significant effect on financial performance, if Islamic banks can maintain and run their companies according to Islamic principles consistently, so that this can provide a distinction between Islamic and conventional banks and can trigger customer interest in using Islamic banking products and this can improve the financial performance of Islamic banking.

\section{REFERENCES}

Azzahra, Khoirunnisa, “The Influence of Human Capital, Structural Capital, and Relational Capital to the performance of cooperation with competitive advantage as intervening variable of cooperation in South Tangerang", 2018

Budiman, Fajar. 2017. "Pengaruh Shariah Compliance dan Islamic Corporate Governance terhadap Kinerja Keuangan Bank Umum Syariah. Universitas Islam Negrei Jakarta: Jakarta.

Bustamam, "Pengaruh Intellectual Capital, Biaya Intermediasi, dan Islamicity Performance Index terhadap Profitabilitas Syariah di Indonesia", 2016

Dewanata, Pandu, "The Effect of Intellectual Capital and Islamicity Performance Index to the Performance of Islamic Bank in Indonesia 2010-2014 Periods", 2016

El Junusi, Rahman. "Implementasi Shariah Governance serta Implikasinya terhadap Reputasi dan Kepercayaan Syariah di Bank Syariah". Al-Tahrir, Volume 12 Nomor 1, Mei, 2012.

Ghazali, Imam. 2011. Aplikasi Analisis Multivariate dengan Program IBM 19. Semarang: Badan Penerbit Universitas Diponegoro.

Ghazali, Imam. 2013. Aplikasi Analisis Multivariate dengan Program SPSS, Badan Penerbit UNDIP. Semarang.

Ikatan Akuntansi Indonesia. "Standar Akuntansi Keuangan”. Jakarta: Salemba Empat. 2007.

Kartika, Martha, "Pengaruh Intellectual Capital pada Profitabilitas Perusahaan Perbankan yang terdaftar di Bursa Efek Indonesia pada Tahun 2007-2011”, 2013

Maisaroh, Siti, "Pengaruh Intellectual Capital dan Islamicity Performance Index terhadap Profitability Perbankan Syariah Indonesia", 2015

Nurkhasanah, Anita "Pengaruh Intellectual Capital dan Islamicity Performance Index terhadap Kinerja Keuangan Perbankan Syariah di Indonesia”, 2016

Rahma, Yusro, "The Effect of Intellectual Capital and Islamic Performance Index onFinancial Performance", 2018

Tuffahati, "Pengaruh Intellectual Capital, Biaya Intermediasi, dan Islamicity Performance Index terhadap Profitabilitas Syariah di Indonesia”, 2018 
JARES, Vol. 5 No. 1 March, 2020; p-ISSN: 2502-826X; e-ISSN: 2503-1163

Copyrights@ Balitar Islamic University, Blitar, Indonesia;

https://ejournal.unisbablitar.ac.id/index.php/jares

Citation: Azzahra, K. (2020). THE INFLUENCE OF INTELLECTUAL CAPITAL AND SHARIA

COMPLIANCE TO THE BANKING FINANCIAL PERFORMANCE IN INDONESIA. JARES

(Journal of Academic Research and Sciences), 5(1), 14-26. https://doi.org/10.35457/jares.v5i1.900

Ulum, Ihyaul. (2009). Konstruksi model pengukuran kinerja dan kerangka kerja pengungkapan modal intelektual

Ulum, Ihyaul, (2009), Intellectual Capital : Konsep dan kajian empiris, Graha Ilmu, Yogyakarta

Wendry, "Pengaruh Intellectual Capital Terhadap Kinerja Keuangan BankUmum Syariah yang terdaftar pada Bank Indonesia periode 2010-2015”, 2016 